Article

\title{
Effects of Beetroot Juice Supplementation on Performance and Fatigue in a 30-s All-Out Sprint Exercise: A Randomized, Double-Blind Cross-Over Study
}

\author{
Eduardo Cuenca ${ }^{1}$, Pablo Jodra ${ }^{2,3}$, Alberto Pérez-López 4 (iD), Liliana G. González-Rodríguez ${ }^{2,5}$, \\ Sandro Fernandes da Silva ${ }^{6}$, Pablo Veiga-Herreros ${ }^{2}$ and Raúl Domínguez ${ }^{7, *}$ \\ 1 GRI-AFIRS, Escuela de Ciencias de la Salud, TecnoCampus-Universidad Pompeu Fabra, Mataró, \\ 08005 Barcelona, Spain; educuen@hotmail.com \\ 2 Faculty of Health Sciences, University Alfonso X El Sabio, 28691 Madrid, Spain; pjodrjim@uax.es (P.J.); \\ liligoro@uax.es (L.G.G.-R.); pveigher@uax.es (P.V.-H.) \\ 3 Department of Education Sciences, University of Alcalá, 28805 Alcalá de Henares, Spain \\ 4 Department of Biomedical Sciences, Faculty of Medicine and Health Sciences, University of Alcalá, \\ 28805 Alcalá de Henares, Spain; alberto_perez-lopez@hotmail.com \\ 5 Investigation Group Valornut, Department of Nutrition, Faculty of Pharmacy, \\ University Complutense de Madrid, 28691 Madrid, Spain \\ 6 Studies Research Group in Neuromuscular Responses (GEPE N), University of Lavras, 37200-000 Lavras, \\ Brazil; sandrofs@gmail.com \\ 7 Faculty of Health Sciences, University Isabel I, 09004 Burgos, Spain \\ * Correspondence: raul_dominguez_herrera@hotmail.com or raul.dominguez@ui1.es; Tel.: +34-695-182-853
}

Received: 3 August 2018; Accepted: 31 August 2018; Published: 4 September 2018

\begin{abstract}
As a nitric oxide precursor, beetroot juice (BJ) is known to enhance high-intensity exercise performance $\left(80-100 \% \mathrm{VO}_{2 \max }\right)$ yet its impacts on higher intensity sprint exercise $\left(>100 \% \mathrm{VO}_{2 \max }\right)$ remain to be established. This study sought to examine the effects of BJ supplementation on performance and subsequent fatigue during an all-out sprint exercise. Using a randomized cross-over, double-blind, placebo-controlled design, 15 healthy resistance-trained men (22.4 \pm 1.6 years) ingested $70 \mathrm{~mL}$ of either BJ or placebo. Three hours later, participants undertook a 30-s all-out Wingate test. Before and after the sprint exercise and at $30 \mathrm{~s}$ and $180 \mathrm{~s}$ post-exercise, three countermovement jumps (CMJ) were performed and blood lactate samples were obtained. Compared to placebo, BJ consumption improved peak (placebo vs. BJ, $848 \pm 134$ vs. $881 \pm 135 \mathrm{~W} ; p=0.049$ ) and mean (641 \pm 91 vs. $666 \pm 100 \mathrm{~W} ; p=0.023$ ) power output and also reduced the time taken to reach $\mathrm{W}_{\text {peak }}$ in the Wingate test $(8.9 \pm 1.4$ vs. $7.3 \pm 0.9 \mathrm{~s} ; p=0.003)$. No differences were detected in the fatigue index. In addition, while over time CMJ height and power diminished (ANOVA $p<0.001$ ) and blood lactate levels increased (ANOVA $p<0.001$ ), no supplementation effect was observed. Our findings indicate that while BJ supplementation improved performance at the 30-s cycling sprint, this improvement was not accompanied by differences in fatigue during or after this type of exercise.
\end{abstract}

Keywords: nitric oxide; nitrates; muscle power; muscle fatigue

\section{Introduction}

Dietary nitrate supplementation has been described as a potential ergogenic aid for high-intensity exercise efforts $\left(80-100 \% \mathrm{VO}_{2 \max }\right)$ as it reduces the oxygen cost of ATP synthesis and ATP cost of muscle contraction thus improving muscle contraction/relaxation, force and power production [1-3]. However, the impacts of nitrate supplementation on all-out sprint exercise 
performance ( $>100 \% \mathrm{VO}_{2 \max }$ ), and particularly its effects on the fatigue induced by this mode of exercise [4-6] have been scarcely addressed.

Ingested nitrate $\left(\mathrm{NO}_{3}{ }^{-}\right)$is a well-known precursor of nitric oxide (NO) in humans [7]. Around $25 \%$ of circulating $\mathrm{NO}_{3}{ }^{-}$is taken up by salivary gland acinar cells in a process facilitated by sialin [8,9]. Oral microorganisms, particularly those on the posterior aspect of the tongue, initiate the reduction of $\mathrm{NO}_{3}{ }^{-}$ into nitrite $\left(\mathrm{NO}_{2}{ }^{-}\right)$, which subsequently in the stomach and gut, can be converted into $\mathrm{NO}$ and be absorbed under hypoxic conditions [8-10]. The majority of the remaining $\mathrm{NO}_{3}{ }^{-}$and $\mathrm{NO}_{2}{ }^{-}$molecules that reach the intestine are absorbed by this organ increasing NO levels in blood [9]. NO offers several exercise adaptation benefits [11] through its effects of inducing vasodilatation, reducing blood viscosity, and promoting muscular oxygen perfusion and gas exchange [12]. In skeletal muscle, NO reduces oxidative stressor production and promotes mitochondrial biogenesis and efficiency $[13,14]$. Moreover, $\mathrm{NO}$ it is also able to increase force and power production during muscle contraction, decreasing the cost of ATP needed as well as the oxygen required to synthesize ATP [1-3].

Beetroot juice (BJ) is a $\mathrm{NO}_{3}{ }^{-}$-rich supplement commonly used because of its high betacyanin and polyphenol contents that promote $\mathrm{NO}$ synthesis to a greater extent than other $\mathrm{NO}_{3}{ }^{-}$salts $[15,16]$. The ergogenic effect of $\mathrm{NO}_{3}{ }^{-}$supplementation was initially observed in terms of metabolic adaptations to endurance training [17]. However, despite the known impact of $\mathrm{BJ}$ on aerobic performance, recent data indicate a potential effect of $\mathrm{NO}_{3}{ }^{-}$-rich supplements on anaerobic exercise [4].

Interestingly, the observed benefits of BJ only seem to affect type II muscle fibers [11]. In these fibers, NO stimulates calcium release into the sarcoplasm via calsequestrin upregulation [18] and reduces the phosphocreatine degradation rate, decreasing ATP cost across several ranges of exercise intensity [19]. During sprint exercise $\left(>100 \% \mathrm{VO}_{2 \max }\right)$, type II muscle fibers are mainly recruited to satisfy the high muscle contraction demands. In these glycolytic fibers, exercise leads to a reduced $\mathrm{pH}$ in comparison to oxidative fibers. Intra-cell acidity also promotes the reduction of $\mathrm{NO}_{2}{ }^{-}$to $\mathrm{NO}$ [8]. In turn, the increase in NO availability may diminish the ATP and phosphocreatine required by each muscle contraction with the consequence of an ergogenic effect of $\mathrm{NO}_{3}{ }^{-}$supplementation in sprint exercise achieved by improving power production and attenuating the fatigue induced by this exercise mode [20,21].

However, despite acute BJ administration emerging as an effective strategy to improve different modes of exercise performed to exhaustion [22], the influence of this supplement has been scarcely explored in sprint exercise [1-3,20,23,24]. Two studies have shown that BJ supplementation increases peak power output in a 3-4 s [23] or $30 \mathrm{~s}$ cycle ergometer exercise $[20,23,24]$. However, the benefits of $\mathrm{BJ}$ on the muscle power produced in a vertical jump have not been investigated. The countermovement jump (CMJ) is a useful test to explore the muscle contractile properties and neuromuscular performance of the lower-limbs [25]. This test has been extensively used in high-intensity sports in which the stretch-shortening cycle plays a pivotal role [26]. Further, given that fatigue can be defined as a reduction in strength or power regardless of the ability to sustain a required task [27], conducting the $\mathrm{CMJ}$ before and after an extenuating task is an effective method of monitoring muscle fatigue [28]. In this context, the present study was designed to examine the effects of $\mathrm{BJ}$, as a $\mathrm{NO}_{3}{ }^{-}$-rich supplement, on performance at a single 30-s all-out sprint exercise and the fatigue caused by the exercise bout. Our working hypothesis was that $\mathrm{BJ}$ intake would increase the peak power generated by muscle contraction and reduce the time needed to achieve this peak power output with the consequence of diminished neuromuscular fatigue after the sprint.

\section{Materials and Methods}

\subsection{Participants}

Fifteen young men (age $22.4 \pm 1.6$ years, height $178 \pm 6 \mathrm{~cm}$, weight $76.9 \pm 10.3 \mathrm{~kg}$ ) were recruited. All subjects had at least 18 months of experience with resistance exercise, training 3 sessions per week (e.g., bench press and leg press 1RM were 1.0 and 1.5-fold higher than their body mass weight, 
respectively) and were familiar with the 30-s all-out Wingate and CMJ tests. Subjects were instructed to refrain from taking sports supplements, medical supplements or any ergogenic aids during the 3 months before the tests and were excluded if they failed to comply. Further exclusion criteria were smoking or cardiovascular, pulmonary, metabolic or neurologic disease.

Candidate participants were first informed of the experimental protocol before giving their written consent. The study was approved by the Ethics Committee of Alfonso X University in (code 1.010.704) accordance with the latest version (7th) of the Declaration of Helsinki.

\subsection{Experimental Design}

The study design was randomized cross-over, placebo-controlled and double-blind. Participants reported to the laboratory on two separate days under the same experimental conditions ( $72 \mathrm{~h}$ between sessions, $0.5 \mathrm{~h}$ difference in test initiation). Participants were instructed to avoid any form of exercise in the $72 \mathrm{~h}$ leading up to each test.

In session 1, participants were subjected to a preliminary assessment of body composition and underwent a familiarization session of the experimental protocol. Then, on two separate occasions (sessions 2 and 3) as they arrived at the laboratory, participants were provided with a supplement containing either placebo (placebo) or BJ. The trial was double-blinded such that one researcher (P.V.-H.) allocated all the participants' drinks in a counter-balanced fashion (in each trial 50\% of participants ingested placebo and 50\% ingested BJ beverages) with random assignment to each supplement (using Excel, Microsoft, Washington, DC, USA) and this researcher did not take part in the subsequent experimental procedures or statistical analysis of data. Three hours after taking the supplement, all participants performed a $30 \mathrm{~s}$ all-out Wingate test on a Monark ergometer (Ergomedic 828E, Vansbro, Sweden), as previously described [19]. Strong verbal encouragement was provided in all the sprint tests. In addition, data were collected in three CMJ jumps and blood samples for lactate determination were obtained in duplicate before (Pre) and after the sprint exercise at $30 \mathrm{~s}$ (Post) and $180 \mathrm{~s}$ post-exercise (Post-3). The study procedure is illustrated in Figure 1.

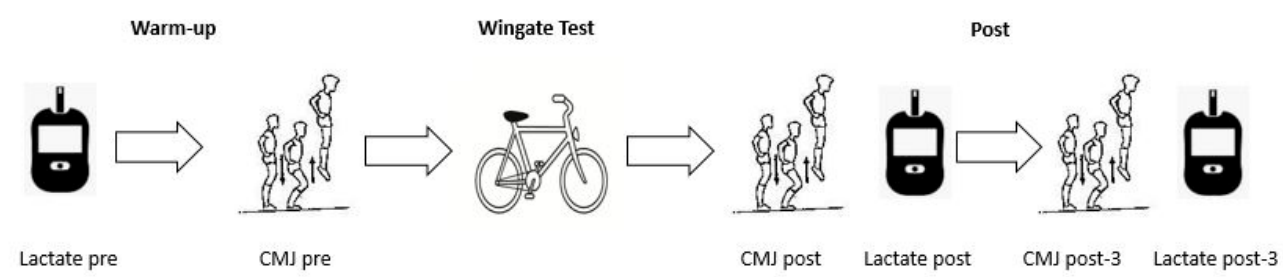

Figure 1. Experimental procedure.

\subsection{Placebo vs. BJ Ingestion}

After an overnight fast, participants reported to the laboratory $3 \mathrm{~h}$ before the first CMJ jump test. Upon arrival, they were provided with either $70 \mathrm{~mL}$ of BJ (containing $6.4 \mathrm{mmol}$ of $\mathrm{NO}_{3}{ }^{-}$) or the same drink lacking $\mathrm{NO}_{3}{ }^{-}$(placebo, $0.04 \mathrm{mmol}$ of $\mathrm{NO}_{3}{ }^{-}$) (Beet-It-Pro Elite Shot, James White Drinks Ltd., Ipswich, UK) as described elsewhere [20].

All participants were instructed to follow a diet sheet the day before each trial that consisted of $60 \%$ carbohydrates, $30 \%$ fat and $10 \%$ proteins. Dietary $\mathrm{NO}_{3}{ }^{-}$was limited by providing subjects a list of $\mathrm{NO}_{3}{ }^{-}$-rich foods (e.g., beetroot, celery or spinach) they should avoid in the $48 \mathrm{~h}$ before each trial. Also, in the $24 \mathrm{~h}$ leading up to each test, subjects were encouraged to avoid brushing their teeth or use an oral antiseptic rinse, or ingest gum, sweets or stimulants (e.g., caffeine) that could alter the oral microbiota and interfere with $\mathrm{NO}_{3}{ }^{-}$reduction.

\subsection{Sprint Performance Variables}

Power output $(\mathrm{W})$ was monitored second-by-second in all sprints. Mean power output $\left(\mathrm{W}_{\text {mean }}\right)$ was calculated as the average power generated during the 30-s test. Peak power output $\left(\mathrm{W}_{\text {peak }}\right)$ was 
taken as the highest $\mathrm{W}$ value recorded. The time (s) taken to reach $W_{\text {peak }}$ was also recorded. Minimum power output $\left(\mathrm{W}_{\min }\right)$ was considered as the lowest $W$ value recorded during the 10 last seconds of the test. Finally, the fatigue index (FI) was calculated using the equation: $\mathrm{FI}=\left(\mathrm{W}_{\text {peak }}-\mathrm{W}_{\text {min }}\right) / \mathrm{W}_{\text {peak }}$. In addition, mean power output in each Wingate test was calculated for the entire test (30 s) and at $10 \mathrm{~s}$ ( $W_{\text {mean0-10s }}, W_{\text {mean10-20s }}$ and $\left.W_{\text {mean20-30s }}\right)$ and 15 s intervals $\left(W_{\text {mean0-15 }}\right.$ and $\left.W_{\text {mean15-30s }}\right)$ as described elsewhere [19].

\subsection{Neuromuscular Fatigue}

Neuromuscular fatigue in the legs was measured as the loss of height and power in a CMJ test performed on a force platform (Quattro Jump model 9290AD; Kistler Instruments, Winterthur, Switzerland) [28-30]. Participants were highly familiarized with this vertical jump test. Two CMJ were performed before (Pre) and after the Wingate test at $30 \mathrm{~s}$ (Post-1) and $180 \mathrm{~s}$ post-exercise (Post-3). At each time-point, mean values of height $(\mathrm{cm})$, mean power $\left(\mathrm{CMJ} \mathrm{Wmean}_{\mathrm{W}}\right)$ and peak power $\left(\mathrm{CMJ}_{\mathrm{Wpeak}}\right)$ were recorded.

\subsection{Blood Lactate}

Before the first CMJ and immediately after the subsequent vertical jumps, capillary blood samples $(5 \mu \mathrm{L})$ were obtained from the index finger of the right-hand for lactate determination using a Lactate ProTM 2 LT-1710 Instrument (Arkray Fatory Inc., KDK Corporation, Shiga, Japan).

\subsection{Statistical Analysis}

The Shapiro-Wilk test was first performed to assess the distribution of the data. Then paired $t$-tests for normally-distributed data and the Wilcoxon test for non-normally distributed variables (Time-to- $W_{\text {peak }}, W_{0-15 s}, W_{15-30 s}, W_{10-20 s}$ and $W_{20-30 s}$ ) were used to compare all sprint variables between the experimental conditions (placebo vs. BJ). A two-way ANOVA for repeated measures was also used to compare placebo vs. BJ for two between-subject conditions: supplementation (placebo vs. BJ) and time (pre-exercise, $30 \mathrm{~s}$ post-exercise and $180 \mathrm{~s}$ post-exercise). Before the ANOVA, we confirmed there was no violation of the sphericity assumption using Mauchly's test of sphericity. Holm-Bonferroni was used as post-hoc test when significant differences were detected. Values are provided as the mean \pm standard deviation (SD). Significance was set at $p<0.05$. All statistical tests were performed using the software package SPSS v.18.0 (SPSS Inc., Chicago, IL, USA).

\section{Results}

\subsection{Sprint Performance Variables}

The effects of placebo and BJ on the 30-s all-out sprint test are shown in Table 1. Compared to placebo, BJ supplementation increased $\mathrm{W}_{\text {peak }}(\sim 3.8 \% ; p=0.049)$ and $\mathrm{W}_{\text {mean }}(\sim 4.0 \% ; p=0.023)$, while reduced time to $W_{\text {peak }}(\sim 18 \% ; p=0.003)$. In 12 of the 15 participants, $W_{\text {peak }}$ was higher after BJ administration compared to the placebo condition (Figure 2). In contrast, no significant differences were observed in $\mathrm{W}_{\min }(\sim 4.4 \% ; p=0.064)$ or FI $(\sim 0.22 \% ; p=0.914)$.

Table 1. Effects of placebo or BJ intake on performance at a 30-s sprint (Wingate) test.

\begin{tabular}{cccc}
\hline Variable & Placebo & BJ & $p$-Value \\
\hline $\mathrm{W}_{\text {peak }}(\mathrm{W})$ & $848 \pm 134$ & $881 \pm 135$ & 0.049 \\
Time to $\mathrm{W}_{\text {peak }}(\mathrm{s})$ & $8.9 \pm 1.4$ & $7.3 \pm 0.9$ & 0.003 \\
$\mathrm{~W}_{\text {mean }}(\mathrm{W})$ & $641 \pm 91$ & $666 \pm 100$ & 0.023 \\
$\mathrm{~W}_{\text {min }}(\mathrm{W})$ & $453 \pm 64$ & $472 \pm 72$ & 0.064 \\
Fatigue index $(\mathrm{FI})(\%)$ & $46 \pm 8$ & $46 \pm 7$ & 0.914 \\
\hline
\end{tabular}

Values are means \pm standard deviation. BJ, beetroot juice. 


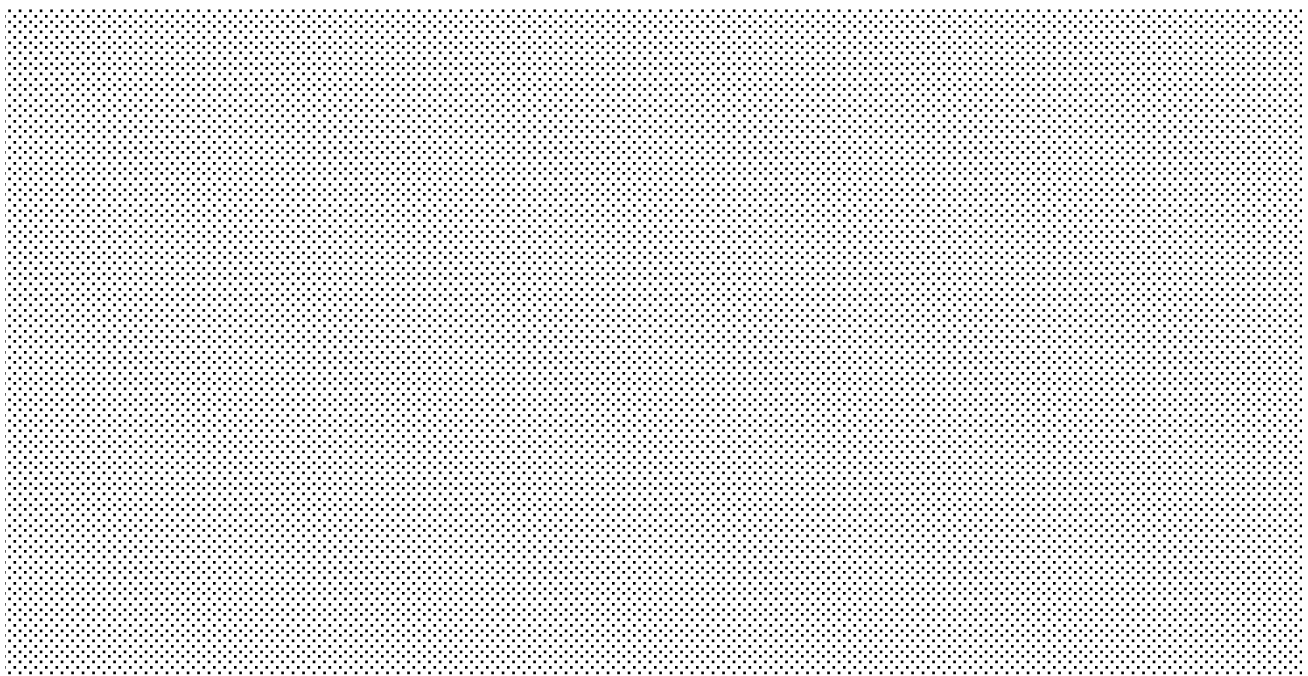

Figure 2. Effects of placebo and BJ intake on $W_{\text {peak }}$ after sprint exercise. Means and individual values are shown as a bold or dotted line respectively. ${ }^{*} p<0.05$ compared to placebo. BJ, beetroot juice.

Values of $W_{\text {mean }}$ were recorded in 10 and $15 \mathrm{~s}$ intervals. Figure 3 displays $W_{\text {mean }}$ values in $15 \mathrm{~s}$ intervals $\left(\mathrm{W}_{0-15 \mathrm{~s}}\right.$ and $\left.\mathrm{W}_{15-30 \mathrm{~s}}\right)$. An increased $\mathrm{W}_{\text {mean }}$ was observed after $\mathrm{BJ}$ intake compared to placebo during the first $15 \mathrm{~s}$ of the sprint (placebo vs. BJ, $709 \pm 113$ vs. $740 \pm 122 \mathrm{~W}_{0-15 \mathrm{~s}} ; p=0.017$ ), while no significant differences were recorded during the last $15 \mathrm{~s} \mathrm{(placebo} \mathrm{vs.} \mathrm{BJ,} 574 \pm 80$ vs. $593 \pm 87 \mathrm{~W}_{15-30 \mathrm{~s}}$; $p=0.173)$.

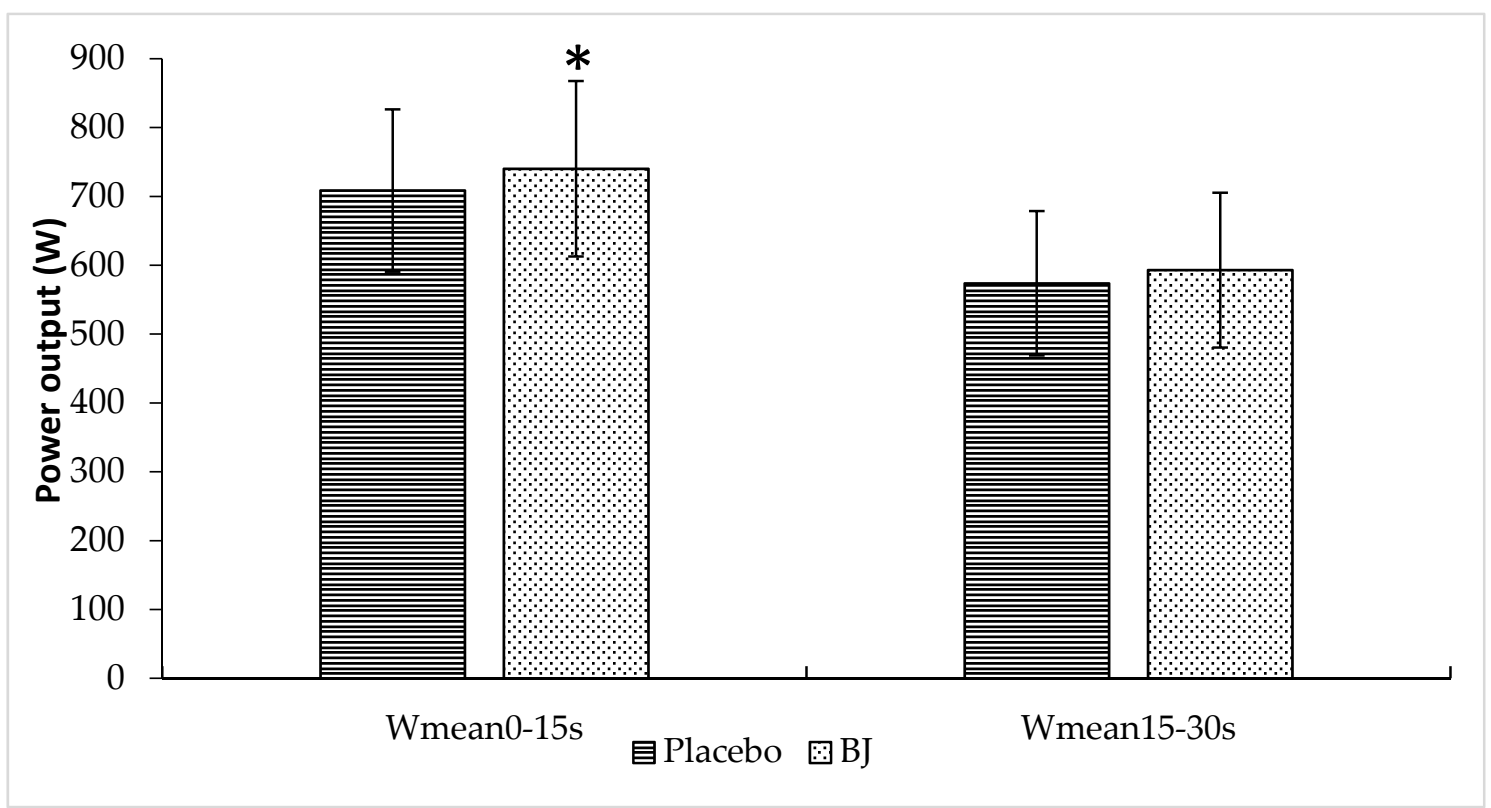

Figure 3. Effects of placebo and $B J$ intake on $W_{\text {mean }}$ values recorded over $15 \mathrm{~s}$ intervals $\left(A, W_{0-15 s}\right.$; $\left.\mathrm{B}, \mathrm{W}_{15-30 \mathrm{~s}}\right)$ after the sprint. ${ }^{*} p<0.05$ compared to placebo.

Figure 4 provides $W_{\text {mean }}$ values in $10 \mathrm{~s}$ intervals $\left(\mathrm{W}_{0-10 \mathrm{~s}}, \mathrm{~W}_{10-20 \mathrm{~s}}\right.$ and $\left.\mathrm{W}_{20-30 \mathrm{~s}}\right)$. Compared to placebo, a significant increase in $\mathrm{W}_{\text {mean }}$ was observed after $\mathrm{BJ}$ intake during the first $10 \mathrm{~s}$ interval (placebo vs. BJ, $683 \pm 118$ vs. $717 \pm 127 \mathrm{~W}_{0-10 \mathrm{~s}} ; 5.0 \%, p=0.043$ ), while no significant differences emerged for the intervals $10-20 \mathrm{~s}$ (placebo vs. BJ, $712 \pm 105 \mathrm{vs.} 735 \pm 113 \mathrm{~W}_{10}-20 \mathrm{~s} ; 3.2 \%, p=0.078$ ) or 20-30 s (placebo vs. BJ, $529 \pm 73$ vs. $548 \pm 79 \mathrm{~W}_{20-30 \mathrm{~s}} ; 3.6 \%, p=0.30$ ). 


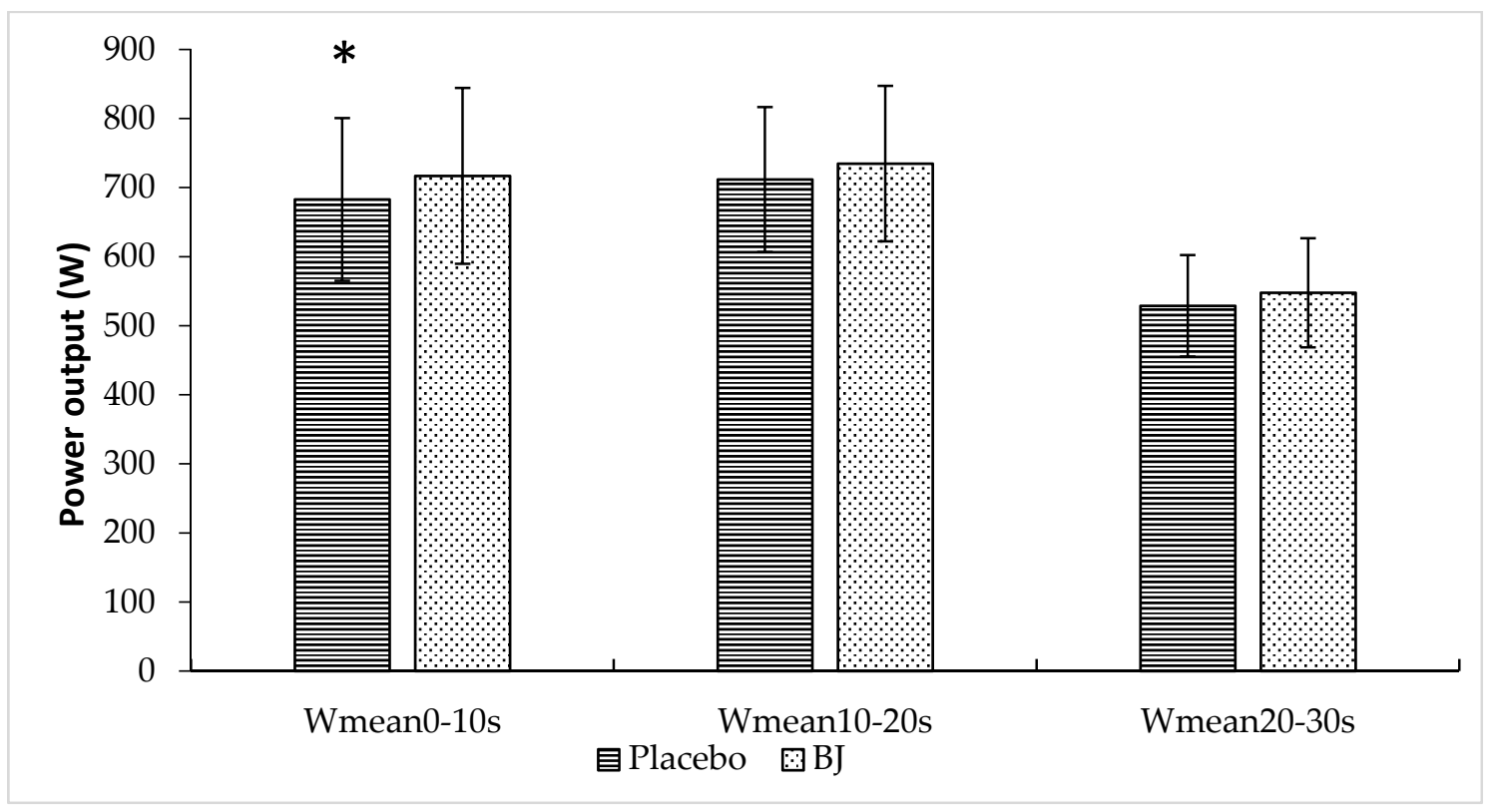

Figure 4. Effects of placebo and $B J$ intake on $W_{\text {mean }}$ values recorded over $10 \mathrm{~s}$ intervals $\left(\mathrm{W}_{\text {mean } 0-10 \mathrm{~s}}\right.$, $W_{\text {mean10-20s }}$ and $\left.W_{\text {mean20-30s }}\right)$ after the sprint. Values are means \pm standard deviation. ${ }^{*} p<0.05$ compared to placebo.

\subsection{Neuromuscular Fatigue and Blood Lactate Concentrations}

The effects of placebo and BJ intake on neuromuscular fatigue measured through the CMJ test are shown in Table 2. The 30-s all-out Wingate test led to significant reductions in $\mathrm{CMJ}_{\text {height }}, \mathrm{CMJ}_{\mathrm{W}_{\text {peak }}}$ and $\mathrm{CMJ}_{W m e a n}($ ANOVA time effect, $p<0.001$ ). Compared to Pre, a significant decrease was observed at Post and Post-3 in CMJ $\mathrm{C}_{\text {height }}$ (Pre vs. Post, 38\%; Pre vs. Post-3, 19\%; $p<0.001$ ), CMJ Wpeak (Pre vs. Post, $28 \%$; Pre vs. Post-3, 10\%; $p<0.001$ ) and CMJ Wmean (Pre vs. Post, $21 \%$; Pre vs. Post-3, 14\%; $p<0.001)$; while a significant increase was observed for Post-3 compared to Post in all variables $(\sim 24 \%$ $\left.\mathrm{CMJ}_{\text {height }}, \sim 22 \% \mathrm{CMJ}_{\text {Wpeak }}, \sim 21 \% \mathrm{CMJ}_{\text {Wmean }} ;<<0.001\right)$. No supplementation or interaction effects (supplement $\times$ time) were observed.

Figure 5 illustrates the blood lactate values recorded after the sprint test. Blood lactate concentration was significantly higher after the 30-s all-out Wingate test (ANOVA time effect, $p<0.001$ ). Compared to Pre (placebo, $1.47 \pm 0.71 \mathrm{mmol} / \mathrm{L} ; \mathrm{BJ}, 1.47 \pm 0.35 \mathrm{mmol} / \mathrm{L}$ ), blood lactate was significantly higher at the time points Post-0.5 (placebo, $13.86 \pm 3.37 \mathrm{mmol} / \mathrm{L} ; \mathrm{BJ}, 14.49 \pm 3.27 \mathrm{mmol} / \mathrm{L} ; p<0.001$ ) and Post-3.5 (placebo, $15.20 \pm 2.62 \mathrm{mmol} / \mathrm{L} ; \mathrm{BJ}, 14.84 \pm 2.32 \mathrm{mmol} / \mathrm{L} ; p<0.001$ ). No supplementation (ANOVA supplementation effect, $p=0.858$ ) or interaction effects (ANOVA supplement $\times$ time effect, $p=0.719)$ were detected.

Table 2. Effects of placebo or BJ intake in a neuromuscular fatigue (CMJ) after a 30-s all-out Wingate test.

\begin{tabular}{|c|c|c|c|c|c|c|c|c|c|}
\hline \multirow{2}{*}{ Variable } & \multicolumn{3}{|c|}{ Placebo } & \multicolumn{3}{|c|}{ BJ } & \multirow{2}{*}{ Suppl. } & \multirow{2}{*}{ Time } & \multirow{2}{*}{ Suppl. $\times$ Time } \\
\hline & Pre & Post & Post-3 & Pre & Post & Post-3 & & & \\
\hline $\mathrm{CMJ}_{\text {height }}(\mathrm{cm})$ & $30.8 \pm 4.6$ & $19.5 \pm 5.1^{\mathrm{a}}$ & $25.0 \pm 4.3^{\mathrm{a}, \mathrm{b}}$ & $31.5 \pm 3.4$ & $19.0 \pm 4.2^{\mathrm{a}}$ & $25.3 \pm 4.2^{\mathrm{a}, \mathrm{b}}$ & 0.863 & $<0.001$ & 0.864 \\
\hline
\end{tabular}

Values are means \pm standard deviation. ${ }^{\mathrm{a}} p<0.05$ compared to Pre; ${ }^{\mathrm{b}} p<0.05$ compared to Post. Pre, before sprint exercise; Post, post-exercise; Post-3, 3 min post-exercise. 


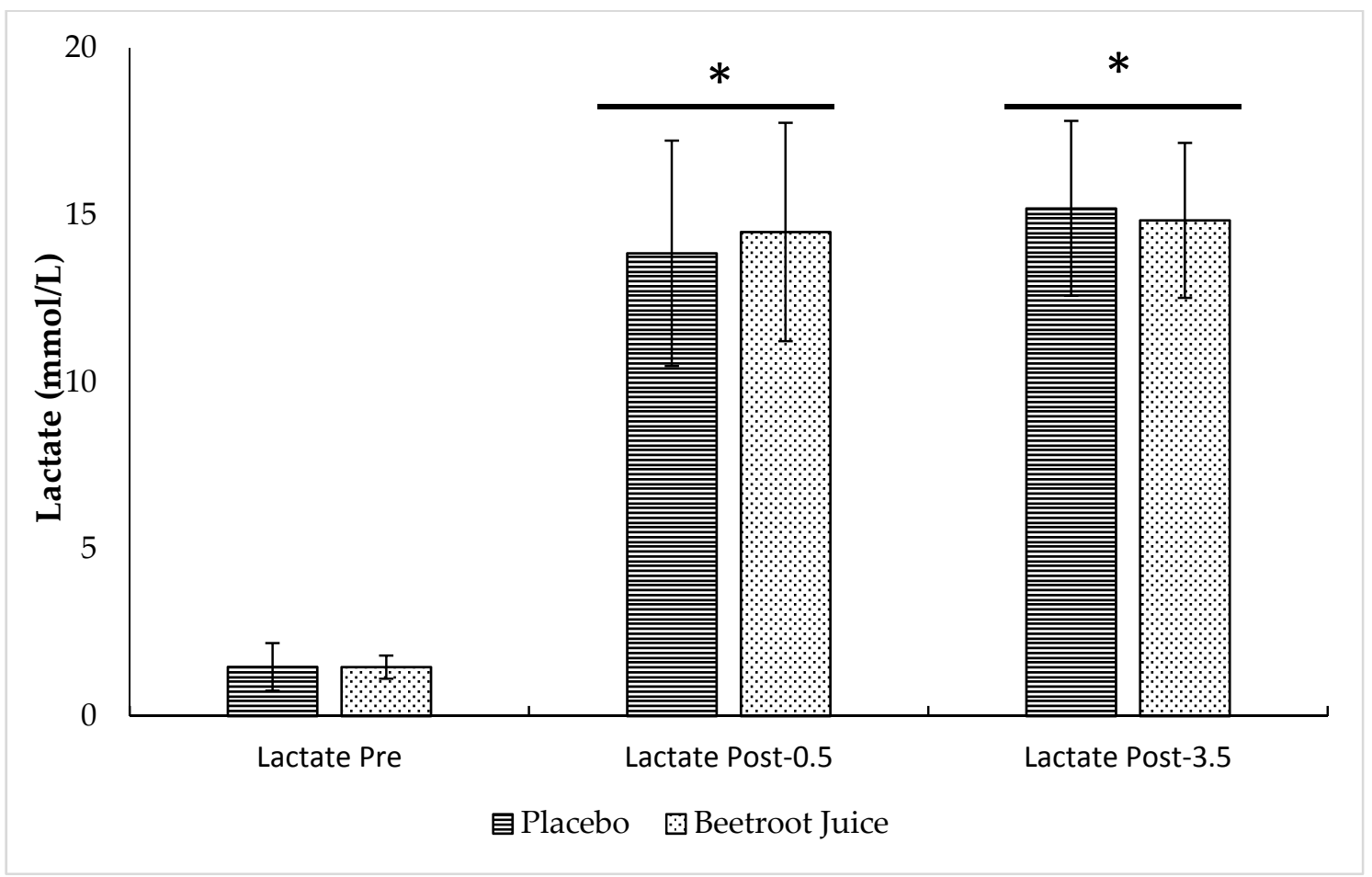

Figure 5. Blood lactate concentrations recorded after the sprint for the placebo and BJ conditions. Values are means \pm standard deviation. ${ }^{*} p<0.05$ compared to Pre. Pre, before sprint exercise; Post-0.5, 0.5 min post-exercise; Post-3.5, 3.5 min post-exercise.

\section{Discussion}

The findings of our study indicate that BJ supplementation enhances peak and mean power output, particularly during the first half of a 30-s all-out sprint test, reducing the time taken to reach peak power output. Despite this improved sprint performance, neuromuscular fatigue caused by this exercise mode was similar after the intake of $\mathrm{BJ}$ or placebo. These observations suggest that $\mathrm{NO}_{3}{ }^{-}$-rich supplements enhance sprint performance without producing cumulative impacts on fatigue levels.

$\mathrm{NO}_{3}{ }^{-}$supplementation has been linked to an increase in $\mathrm{W}_{\text {peak }}$ generated by leg extension in an isokinetic machine at several angular velocities (from 0 to $6.28 \mathrm{rad} / \mathrm{s}$ ) in healthy subjects $(\sim 5-6 \%)$ [2,31] and patients with heart disease $(\sim 12 \%)$ [32]. There are two reports in the literature of investigations examining the effects of an acute dose of BJ on a 30-s all-out Wingate test $[19,23]$. In the study by Domínguez et al. [20], a significant increase in $W_{\text {peak }}$ was observed $(\sim 6 \%)$ while Rimer et al. [23] observed no such effect. It should be mentioned that in the study by Rimer's group [23], the 30-s Wingate test was performed after 4 series of 3-4 s all-out sprint trials and 5 min of passive rest; and despite the lack of difference in the Wingate test, the delta change in peak power output produced in the 3-4 sprints indicated an increase of $\sim 6.0 \%$ after BJ intake compared to placebo. In the present study, a similar increase in peak power output was observed after the 30-s all-out Wingate test $(\sim 4 \%)$ and this performance improvement seems to occur during the first $15 \mathrm{~s}$ of the sprint and hereafter decline. These data indicate that BJ supplementation may cause a transient ergogenic elevation of peak power output during the first few seconds of sprint exercise, and that this effect could be attenuated after several doses of BJ [6].

The use of an isokinetic or isoinertial cycle ergometer for the sprint test may be a confounding factor when examining the ergogenic effect of BJ supplementation $[19,23]$. In this study, we used an isoinertial cycle ergometer, which measures power output based on a variable pedaling rate at a fixed load (7.5\% body mass) [20]. In contrast, using an isokinetic cycle ergometer, the pedaling rate is predetermined [23]. Pedaling rate is strongly related to the angular velocity of the knee and hip, and 
can be used as an indicator of muscle contraction velocity [33] and type II motor unit recruitment [34]. An ergogenic effect of BJ intake has been observed not only in sprint exercise [20] but also in other tasks (e.g., leg extension) under elevated angular velocities [2,31,32]. Consistent with this idea, the present data revealed a greater effect of BJ on sprint performance $\left(W_{\text {peak }}\right.$ and time to $\left.W_{\text {peak }}\right)$ for the higher angular velocities.

Animal studies have shown that NO increases acetylcholine activity, particularly in type II motor units, which amplify depolarization of the muscle fibers [35] whereas BJ supplementation induces the elevation of intracellular $\mathrm{Ca}^{2+}$ concentrations accompanied by calsequestrin 1 and dihydropyridine receptor upregulation in fast-twitch muscles [18]. Although these mechanisms have not yet been proven in humans, $\mathrm{NO}_{3}{ }^{-}$supplementation likely increases force production by inducing type II muscle fiber depolarization and increasing myoplasm $\mathrm{Ca}^{2+}$ concentrations facilitating muscle contraction [18,36] by increasing the number of actin-myosin cross-bridges [37]. This improvement in muscle force production in response to BJ consumption has been detected as a higher rate of force development (RFD) [37] through increased peak power output, the time taken to reach that power output and a faster reaction time [4]. In effect, Time to $W_{\text {peak }}$ and reaction time are key factors in sports performance, particularly in disciplines in which acceleration determines performance [38,39]. Here, BJ supplementation led to a pronounced reduction in Time to $W_{\text {peak }}$ during a 30-s all-out Wingate test, coinciding with previous data in which the increase in $W_{\text {peak }}$ was accompanied by a shorter time needed to reach $W_{\text {peak }}[20]$. A reduced Time to $W_{\text {peak }}$ was also found when a transient increase in $W_{\text {peak }}$ was not detected after prolonged doses of BJ supplements and repeated sprint exercise [6]. In these two previous studies [6,20], the shortened Time to $W_{\text {peak }}$ was lower $(\sim 0.7$ and $\sim 0.2 \mathrm{~s}$, respectively) than the difference observed here $(\sim 1.6 \mathrm{~s})$. The greater improvement in Time to $W_{\text {peak }}$ reported here may be explained by a reduced level of anaerobic training of our subjects compared to participants of the studies by Dominguez et al. [20] and Jonvik et al. [6], who were well-trained in anaerobic disciplines.

Anaerobic pathways supply $\sim 75 \%$ of energy requirements in a 30-s all-out sprint exercise $[40,41]$. During the first $6 \mathrm{~s}$, ready to use sources of energy are needed to produce maximal peak power output in the shortest time possible. Accordingly, free ATP and PCr stores are critical during the initial part of a sprint [42]. At this time (first 5-10 s), a marked depletion in PCr stores occurs and this compromises power output coinciding with the time at which glycolysis attains its maximum rates [43]. Along with an increased force production capacity, BJ supplementation leads to the reduced ATP cost of muscle contraction $[19,44]$ perhaps by reducing PCr degradation rates. The reduced ATP requirements of muscle contraction together with the maintenance of free ATP and PCr stores promoted by $\mathrm{NO}_{3}{ }^{-}$ supplementation may give rise to a higher power output during a longer period of time coinciding with the increase in mean power output produced during the first $15 \mathrm{~s}$ of the sprint after BJ intake.

Since BJ consumption led to elevated peak and mean power output during the first $15 \mathrm{~s}$ of the sprint, we could argue that the muscular fatigue that takes place during the last $15 \mathrm{~s}$ and at the end of the sprint will be exaggerated.

The fatigue index calculated during the sprint indicated no differences between the supplements. In addition to the mentioned maintenance of anaerobic sources of energy production, the contribution of aerobic energy production increases during the last $15 \mathrm{~s}$ of a Wingate test $[41,43]$. Since $\mathrm{NO}_{3}{ }^{-}$ supplementation is known to reduce the oxygen cost of ATP synthesis [45] and to preserve ATP and PCr stores [19], the lack of differences between supplements (placebo vs. BJ) may be explained by a higher capacity of $\mathrm{NO}_{3}{ }^{-}$to induce ATP store maintenance and thus reduce the cost of its synthesis by both aerobic and anaerobic sources.

Immediately after the sprint exercise, two CMJ jumps were performed at $30 \mathrm{~s}$ and $180 \mathrm{~s}$. CMJ is a vertical jump test that assesses muscle contractile properties and neuromuscular performance (anaerobic power) of the lower-limbs [46,47]. Variables such as CMJ height and power have also been used as indicators of neuromuscular fatigue $[48,49]$. Some authors have argued that the CMJ test after extenuating exercise [28] serves to assess muscle capacity to replenish $\sim 50 \%$ of depleted PCr stores at 30-s post-exercise [50] and to recover almost completely depleted PCr stores at $180 \mathrm{~s}$ post-exercise [51]. 
Hence a pronounced reduction in CMJ performance (height and power) after $180 \mathrm{~s}$ will reflect the diminished $\mathrm{PCr}$ store replenishment capacity of muscle fibers affecting the stretch-shortening cycle and force production [52]. The present observations are in good agreement with prior findings in which an effect of time in reducing CMJ height and mean power output was seen after a 30-s all-out Wingate test [28-30]. The decrease in CMJ performance was more pronounced at $30 \mathrm{~s}(\sim 30 \%)$ compared to $180 \mathrm{~s}$ post-exercise $(\sim 10 \%)$. However, no differences between supplementation conditions were observed.

In our study, BJ supplementation overall did not give rise to a greater fatigue index during the second half of the test or to neuromuscular fatigue as measured in CMJ tests, after the 30-s all-out sprint test. These results indicate that the improved sprint performance induced by $\mathrm{BJ}$ as a $\mathrm{NO}_{3}{ }^{-}$-rich supplement may not be accompanied by more fatigue.

\section{Limitations}

Our study has several limitations. $\mathrm{BJ}$ is a $\mathrm{NO}_{3}{ }^{-}$-rich supplement known to increase circulating $\mathrm{NO}_{2}{ }^{-}$and $\mathrm{NO}$ levels [7]. However, these levels were not measured before the intake by the participants of placebo or BJ. Further, the number of subjects recruited $(N=15)$, although appropriate for this type of study, limits the detection of small changes that could be the consequence of BJ administration. Finally, participants were not trained cyclists and therefore the ergogenic effects produced by BJ cannot be directly transferred to this sports modality. On the up-side, however, the inclusion of resistance trained individuals was useful to explore the physiological effects of BJ supplementation on skeletal muscle power production and to examine fatigue induced by a sprint exercise to exhaustion.

\section{Conclusions}

In conclusion, BJ supplementation produced an ergogenic effect in a 30-s all-out Wingate test

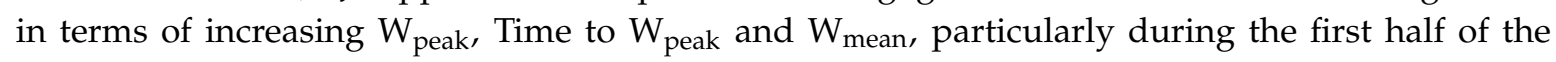
sprint, without increasing muscular fatigue accumulation during or after this extenuating sprint exercise. These findings suggest that $\mathrm{NO}_{3}{ }^{-}$-rich supplements could be a suitable strategy to improve performance in sports modalities in which power and acceleration largely determine performance.

Author Contributions: R.D. and S.F.d.S. designed the experiment; P.J. and P.V.-H. recruited the subjects and hosted the informative session; P.V.-H. and L.G.G.-R. checked that subjects followed the diet guidelines and the timing of supplement ingestion. R.D., E.C., P.J., P.V.-H. and L.G.G.-R. performed the experiments; E.C., A.P.-L. and S.F.d.S. analyzed the data; R.D. and S.F.d.S. conducted the statistical analysis; and R.D., E.C., P.J., P.V.-H., L.G.G.-R. A.P.-L. and S.F.d.S. wrote the manuscript.

Funding: Publication and translation costs will be met using funds from the competitive project of the VIII Announcement of the Banco Santander and Fundación UAX (project: 1010704).

Conflicts of Interest: The authors declare no conflict of interest.

\section{References}

1. Haider, G.; Folland, G.P. Nitrate Supplementation Enhances the Contractile Properties of Human Skeletal Muscle. Med. Sci. Sports Exerc. 2014, 46, 2234-2243. [CrossRef] [PubMed]

2. Coggan, A.R.; Leibowitz, J.L.; Kadkhodayan, A.; Thomas, D.P.; Ramamurthy, S.; Spearie, C.A.; Waller, S.; Farmer, M.; Peterson, L.R. Effect of acute dietary nitrate intake on maximal knee extensor speed and power in healthy men and women. Nitric Oxide 2015, 48, 16-21. [CrossRef] [PubMed]

3. Whitfield, J.; Ludzki, A.; Heigenhauser, G.; Senden, S.; Verdijk, L.; Van, L.; Spriet, L.L.; Holloway, G.P. Beetroot Juice Supplementation Reduces Whole Body Oxygen Consumption But Does Not Improve Indices Of Mitochondrial Efficiency in Human Skeletal Muscle. J. Physiol. 2016, 594, 421-435. [CrossRef] [PubMed]

4. Thompson, C.; Vanhatalo, A.; Fulford, J.; Carter, J.; Nyman, L.; Bailey, S.J.; Jones, A.M. Dietary nitrate supplementation improves sprint and high-intensity intermittent running performance. Nitric Oxide 2016, 61, 55-61. [CrossRef] [PubMed] 
5. Thompson, C.; Wylie, L.J.; Blackwell, J.R.; Fulford, J.; Black, M.I.; Kelly, J.; McDonagh, S.T.; Carter, J.; Bailey, S.J.; Vanhatalo, A.; et al. Influence of dietary nitrate supplementation on physiological and muscle metabolic adaptations to sprint interval training. J. Appl. Physiol. 2018, 18, 642-652. [CrossRef] [PubMed]

6. Jonvik, K.L.; Nyakayiru, J.; Van Dicj, J.W.; Maase, K.; Ballak, S.B.; Senden, J.M.G.; Van Loon, L.J.C.; Verdjik, L.B. Repeated-sprint performance and plasma responses following beetroot juice supplementation do not differ between recreational, competitive and elite sprint athletes. Eur. J. Sport Sci. 2018, 18, 524-533. [CrossRef] [PubMed]

7. Maughan, R.J.; Burke, L.M.; Dvorak, J.; Larson-Meyer, D.E.; Peeling, P.; Phillips, S.M.; Rawson, E.S.; Walsh, N.P.; Garthe, I.; Geyer, H.; et al. IOC consensus statement: Dietary supplements and the high-performance athlete. Br. J. Sports Med. 2018, 52, 439-455. [CrossRef] [PubMed]

8. Lundberg, J.O.; Weitzberg, E.; Gladwin, M.T. The nitrate-nitrite-nitric oxide pathway in physiology and therapeutics. Nat. Rev. Drug Discov. 2008, 7, 156-167. [CrossRef] [PubMed]

9. Qu, X.M.; Wu, Z.F.; Pang, B.X.; Jin, L.Y.; Qin, L.Z.; Wang, S.L. From nitrate to nitric oxide: The role of salivary glands and oral bacteria. J. Dent. Res. 2016, 95, 1452-1456. [CrossRef] [PubMed]

10. Tiso, M.; Schechter, A.N. Nitrate reduction to nitrite, nitric oxide and ammonia by gut bacteria under physiological conditions. PLOS ONE 2015, 10, e0119712.

11. Ferguson, S.K.; Hirai, D.M.; Copp, S.W.; Holdsworth, C.T.; Allen, J.D.; Jones, A.M.; Musch, T.I.; Poole, D.C. Impact of dietary nitrate supplementation via beetroot juice on exercising muscle vascular control in rats. J. Physiol. 2013, 591, 547-557. [CrossRef] [PubMed]

12. Erzurum, S.C.; Ghosh, S.; Janocha, A.J.; Xu, W.; Bauer, S.; Bryan, N.S.; Tejero, J.; Hermann, C.; Hille, R.; Stuehr, D.J.; et al. Higher blood flow and circulating NO products offset high-altitude hypoxia among Tibetans. Proc. Natl. Acad. Sci. USA 2007, 104, 17593-17598. [CrossRef] [PubMed]

13. Dejam, A.; Hunter, C.; Schechter, A.; Gladwin, M. Emerging role of nitrite in human biology. Blood. Cells Mol. Dis. 2004, 32, 423-429. [CrossRef] [PubMed]

14. Pinna, M.; Roberto, S.; Milia, R.; Maronquiu, E.; Olla, S.; Loi, A.; Migliaccio, G.M.; Padulo, J.; Orlandi, C.; Tocco, F; et al. Effect of beetroot juice supplementation on aerobic response during swimming. Nutrients 2014, 6, 605-615. [CrossRef] [PubMed]

15. Peri, L.; Pietraforte, D.; Scorza, G.; Napolitano, A.; Fogliano, V.; Minetti, M. Apples increase nitric oxide production by human saliva at the acidic $\mathrm{pH}$ of the stomach: A new biological function for polyphenols with a catechol group? Free Radic. Biol. Med. 2005, 39, 668-681. [CrossRef] [PubMed]

16. Thompson, C.; Vanhatalo, A.; Kadach, S.; Wylie, L.J.; Fulford, J.; Ferguson, S.K.; Blackwell, J.R.; Bailey, S.J.; Jones, A.M. Discrete physiological effects of beetroot juice and potassium nitrate supplementation following 4 weeks sprint interval training. J. Appl. Physiol. 2018, 124, 1519-1528. [CrossRef] [PubMed]

17. Domínguez, R.; Cuenca, E.; Maté-Muñoz, J.L.; García-Fernández, P.; Serra-Paya, N.; Estevan, M.C.; Herreros, P.V.; Garnacho-Castaño, M.V. Effects of beetroot juice supplementation on cardiorespiratory endurance in athletes. A systematic review. Nutrients 2017, 9, 43.

18. Hernández, A.; Schiffer, T.A.; Ivarsson, N.; Cheng, A.J.; Bruton, J.D.; Lundberg, J.O.; Weitzberg, E.; Westerblad, H. Dietary nitrate increases tetanic $\left[\mathrm{Ca}^{2+}\right] \mathrm{i}$ and contractile force in mouse fasttwitch muscle. J. Physiol. 2012, 590, 3575-3583. [CrossRef] [PubMed]

19. Jones, A.M.; Ferguson, S.K.; Bailey, S.J.; Vanhatalo, A.; Poole, D.C. Fiber-type specific effects of dietary nitrate. Exerc. Sci. Sports Rev. 2016, 44, 53-60. [CrossRef] [PubMed]

20. Domínguez, R.; Garnacho-Castaño, M.V.; Cuenca, E.; García-Fernández, P.; Muñoz-González, A.; de Jesús, F.; Lozano-Estevan, M.C.; Fernandes da Silva, S.; Veiga-Herreros, P.; Maté-Muñoz, J.L. Effects of beetroot juice supplementation on a 30-s high-intensity inertial cycle ergometer test. Nutrients 2017, 9, 12. [CrossRef] [PubMed]

21. Domínguez, R.; Maté-Muñoz, J.L.; Cuenca, E.; García-Fernández, P.; Mata-Ordoñez, F.; Lozano-Estevan, M.C.; Veiga-Herreros, P.; Fernandes da Silva, S.; Garnacho-Castaño, M.V. Effects of beetroot juice supplementation on intermittent high-intensity exercise efforts. J. Int. Soc. Sports Nutr. 2018, 15, 2. [CrossRef] [PubMed]

22. Hoon, M.W.; Johnson, N.A.; Chapman, P.G.; Burke, L.M. The Effect of Nitrate Supplementation on Exercise Performance in Healthy Individuals: A Systematic Review and Meta-Analysis. Int. J. Sport Nutr. Exerc. Metab. 2013, 23, 522-532. [CrossRef] [PubMed]

23. Rimer, E.G.; Peterson, L.R.; Coggan, A.R.; Martin, J.C. Increase in Maximal Cycling Power with Acute Dietary Nitrate Supplementation. Int. J. Sports Physiol. Perform. 2016, 11, 715-720. [CrossRef] [PubMed] 
24. Kramer, S.J.; Baur, D.A.; Spicer, M.T.; Vukovich, M.D.; Ormsbee, M.J. The effect of six days of dietary nitrate supplementation on performance in trained CrossFit athletes. J. Int. Soc. Sports Nutr. 2016, 3, 39. [CrossRef] [PubMed]

25. Bobbert, M.F.; van Soest, A.J. Why do people jump the way they do? Exerc. Sport Sci. Rev. 2001, $29,95-102$. [CrossRef] [PubMed]

26. Van Hooren, B.; Zolotarjova, J. The difference between countermovement and squat jump performance: A review of underlying mechanisms with practical applications. J. Strength Cond. Res. 2017, 31, 2011-2020. [CrossRef] [PubMed]

27. Rodacki, A.L.; Fowler, N.E.; Bennett, S.J. Vertical jump coordination: Fatigue effects. Med. Sci. Sports Exerc. 2002, 34, 105-116. [CrossRef] [PubMed]

28. Maté-Muñoz, J.L.; Lougedo, J.H.; Barba, M.; García-Fernández, P.; Garnacho-Castaño, M.V.; Domínguez, R. Muscular fatigue in response to different modalities of CrossFit sessions. PLoS ONE 2017, 12, 0181855. [CrossRef] [PubMed]

29. Garnacho-Castaño, M.V.; Domínguez, R.; Maté-Muñoz, J.L. Understanding the meaning of the lactate threshold in resistance exercises. Int. J. Sports Med. 2015, 36, 371-377. [PubMed]

30. Garnacho-Castaño, M.V.; Domínguez, R.; Ruiz-Solano, P.; Maté-Muñoz, J.L. Acute physiological and mechanical responses during resistance exercise executed at the lactate threshold workload. J. Strength Cond. Res. 2015, 29, 2867-2873. [CrossRef] [PubMed]

31. Coggan, A.R.; Broadstreet, S.R.; Mikhalkova, D.; Bole, I.; Leibowitz, J.L.; Kadkhodayan, A.; Park, S.; Thomas, D.P.; Thies, D.; Peterson, L.R. Dietary nitrate-induced increases in human muscle power: High versus low responders. Physiol. Rev. 2018, 6, 2. [CrossRef] [PubMed]

32. Coggan, A.R.; Leibowitz, J.L.; Spearie, C.A.; Kadkhodayan, A.; Thomas, D.P.; Ramamurthy, S.; Mahmood, K.; Park, S.; Waller, S.; Farmer, M.; et al. Acute dietary nitrate intake improves muscle contractile function in patients with heart failure: A double-blind, placebo-controlled, randomized trial. Circ. Heart Fail. 2015, 8, 914-920. [CrossRef] [PubMed]

33. Martin, J.C.; Brown, N.A.; Anderson, F.C.; Spirduso, W.W. A governing relationship for repetitive muscular contraction. J. Biomech. 2000, 33, 969-974. [CrossRef]

34. Beelen, A.; Sargeant, A.J. Effect of prior exercise at different pedalling frequencies on maximal power in humans. Eur. J. Appl. Physiol. Occup. Physiol. 1993, 66, 102-107. [CrossRef] [PubMed]

35. Petrov, K.A.; Malomouzh, A.L.; Kovyazina, I.V.; Kejci, E.; Nikitashina, A.D.; Prokurina, S.E.; Zobov, V.V.; Nikolsky, E.E. Regulation of acetylcholinesterase activity by nitric oxide in rat neuromuscular junction via N-methyl-D-aspartate receptor activation. Eur. J. Neurosci. 2013, 37, 181-189. [CrossRef] [PubMed]

36. Jorgensen, A.O.; Kalnins, V.I.; Zubrycka, E.; Maclennan, D.H. Assembly of the sarcoplasmic reticulum. Localization by immunofluorescence of sarcoplasmic reticulum proteins in differentiating rat skeletal muscle cell cultures. J. Cell Biol. 1977, 74, 287-298. [PubMed]

37. Marechal, G.; Gailly, P. Effects of nitric oxide on the contraction of skeletal muscle. Cell. Mol. Life Sci. 1999, 55, 1088-1102. [CrossRef] [PubMed]

38. Lockie, R.G.; Murphy, A.J.; Knight, T.J.; Janse de Jonge, X.A. Factors that differentiate acceleration ability in field sport athletes. J. Strength Cond. Res. 2011, 25, 2704-2714. [CrossRef] [PubMed]

39. Mero, A.; Komi, P.V.; Gregor, R.J. Biomechanics of sprint running. A review. Sports Med. 1992, 13, $376-392$. [CrossRef] [PubMed]

40. Calbet, J.A.; Chavarren, J.; Dorado, C. Fractional use of anaerobic capacity during a 30- and 45-s Wingate test. Eur. J. Appl. Physiol. Occup. Physiol. 1997, 76, 308-313. [CrossRef] [PubMed]

41. Calbet, J.A.; De Paz, J.A.; Garatachea, N.; Cabeza de Vaca, S.; Chavarren, J. Anaerobic energy provision does not limit Wingate exercise performance in endurance-trained cyclists. J. Appl. Physiol. 2003, 94, 668-676. [CrossRef] [PubMed]

42. Gaitanos, G.C.; Williams, C.; Boobis, L.H.; Brooks, S. Human muscle metabolism during intermittent maximal exercise. J. Appl. Physiol. 1993, 75, 712-719. [CrossRef] [PubMed]

43. Parolin, M.L.; Chesley, A.; Matsos, M.P.; Spriet, L.L.; Jones, N.L.; Heigenhauser, G.J. Regulation of skeletal muscle glycogen phosphorylase and PDH during maximal intermittent exercise. Am. J. Physiol. 1999, 277, 890-900. [CrossRef]

44. Kerley, C.P. Dietary nitrate as modulator of physical performance and cardiovascular health. Curr. Opin. Clin. Nutr. Metab. Care 2017, 20, 440-446. [CrossRef] [PubMed] 
45. Wylie, L.J.; Mohr, M.; Krustrup, P.; Jackman, S.R.; Ermıdis, G.; Kelly, J.; Black, M.I.; Bailey, S.J.; Vanhatalo, A.; Jones, A.M. Dietary nitrate supplementation improves team sport-specific intense intermittent exercise performance. Eur. J. Appl. Physiol. 2013, 113, 1673-1684. [CrossRef] [PubMed]

46. Bosco, C.; Montanari, G.; Ribacchi, R.; Giovenali, P.; Latteri, F.; Iachelli, G.; Faina, M.; Colli, R.; Dal Monte, A.; La Rosa, M. Relationship between the efficiency of muscular work during jumping and the energetics of running. Eur. J. Appl. Physiol. Occup. 1987, 56, 138-143. [CrossRef]

47. Bosco, C.; Tihanyi, J.; Komi, P.V.; Fekete, G.; Apor, P. Store and recoil of elastic energy in slow and fast types of human skeletal muscles. Acta Physiol. Scand. 1982, 116, 343-349. [CrossRef] [PubMed]

48. Cormie, P.; McBridge, J.M.; McCaulley, G.O. Power-time, force-time, and velocity-time curve analysis of the countermovement jump: Impact of training. J. Strength Cond. Res. 2009, 23, 177-186. [CrossRef] [PubMed]

49. Claudino, J.G.; Cronin, J.; Mezêncio, B.; McMaster, D.T.; McGuigan, M.; Tricoli, V.; Amadio, A.C.; Serrao, J.C. The countermovement jump to monitor neuromuscular status: A meta-analysis. J. Sci. Med. Sport 2017, 20, 397-402. [CrossRef] [PubMed]

50. Skare, O.C.; Skadberg, O.; Wisnes, A.R. Creatine supplementation improves sprint performance in male sprinters. Scand. J. Med. Sci. Sports 2001, 11, 96-102. [CrossRef] [PubMed]

51. Tomlin, D.L.; Wenger, H.A. The Relationship between Aerobic Fitness and Recovery from High Intensity Intermittent Exercise. Sports Med. 2001, 31, 1-11. [CrossRef] [PubMed]

52. Ishikawa, M.; Dousset, E.; Avela, J.; Kyrolainen, H.; Kallio, J.; Linnamo, V.; Komi, P.V. Changes in the soleus muscle architecture after exhausting stretch-shortening cycle exercise in humans. Eur. J. Appl. Physiol. 2016, 97, 298-306. [CrossRef] [PubMed]

(C) 2018 by the authors. Licensee MDPI, Basel, Switzerland. This article is an open access article distributed under the terms and conditions of the Creative Commons Attribution (CC BY) license (http://creativecommons.org/licenses/by/4.0/). 